\title{
Morphologic variations of the superficial palmar $\operatorname{arc}^{1}$
}

\author{
Sílvia Regina Arruda de Moraes ${ }^{2}$ \\ Tâmara Nunes de Araújo ${ }^{3}$ \\ Alexandre Roque da Silva ${ }^{3}$ \\ Amanda Rodrigues de Paula ${ }^{4}$ \\ Juliana Larocerie Salgado ${ }^{4}$
}

\begin{abstract}
Moraes SRA, Araújo TN, Silva AR, Paula AR, Salgado JL. Morphologic variations of the superficial palmar arc. Acta Cir Bras [serial online] 2003 May-Jun;18(3). Available from URL: http:// www.scielo.br/acb.
\end{abstract}

ABSTRACT - The superficial palmar arc ensures the blood supply to the palm of the hand. It is formed by the ulnar artery and the superficial palmar branch of the radial artery (classic pattern), shows a distal convexity, from where three ordinary digital palmar arteries go out. It is located over the flexor muscles of the fingers, the lumbrical muscles, and the branches of the median and the ulnar nerves, under the protection of the palmar aponeurosis. Purpose: The fact of frequent anatomic variations attracted the interest in checking its incidence, improving the knowledge of the territory of the hand aiming clinical and surgical applications. The aim of this study is the observation of the morphology of the superficial palmar arc and the frequency of the variations regarding the contribution of the other arteries to its formation. Methods: To carry out this work, 30 pieces of corpse, fixed in a watery solution of formaldehyde, were studied by the method of macroscopic dissection. The analyzed pieces were designed and photographs were taken, and the obtained results, statistically, applying the test of equality of proportions, had a level of trust of 95\%. Results: An amount of $100 \%$ showed the superficial palmar arc. From these, 18 cases $(60 \%)$ showed anastomosis among the arteries that form the arc and 12 cases (40\%) did not. Concerning about the arterial contribution for the arc formation, the following results were obtained: 11 cases $(36,67 \%)$ were formed by the anastomosis of the ulnar artery with the superficial branch of the radial artery; 7 cases (23\%) were formed by the ulnar artery only; 4 cases $(13,33 \%)$ were formed by the ulnar artery and the superficial branch of the radial artery without anastomosis; 4 cases $(13,33 \%)$ were formed by the anastomosis of the ulnar artery with the main artery of the thumb; 3 cases (10\%) were formed by the anastomosis of the ulnar artery with the median artery of the forearm; 1 case $(3,33 \%)$ was formed by the ulnar artery and the median artery without anastomosis. Conclusion: These results show the incidence of the classic pattern and variations of morphology and different types of contribution for the formation of the superficial palmar arc.

KEY WORDS - Superficial palmar branch. Anastomosis. Morphology.

\section{Introduction}

The superficial palmar arc is important to ensure suitable blood supply to the territory of the hand, maintaining the tissue integrity concerning about the nutrient supply through the arterial blood. It is formed by the anastomosis of the ulnar artery with the superficial palmar branch of the radial artery. It is covered by skin, the short palmar muscle and the palmar aponeurosis, situated over the flexor retinaculum, the short flexor

1. Trabalho realizado no Departamento de Anatomia, Universidade Federal de Pernambuco. Pernambuco - Brasil.

2. Prof. Adjunto do Departamento de Anatomia, Universidade Federal de Pernambuco. Pernambuco - Brasil.

3. Fisioterapeutas.

4. Acadêmicos do Departamento de Terapia Ocupacional, Universidade Federal de Pernambuco. Pernambuco - Brasil. 
muscle of the little finger and the lumbrical muscles, the tendons of superficial flexor muscle of the fingers and sections of the median and the ulnar nerves $1,2,3,4$.

Concerning about its formation, the superficial palmar arc can be indicated by a line that begins in the radial side of the pisiform, bends laterally up to the base of the thumb, with its convexity toward the fingers 1,5,6. Testut and Latarjet ${ }^{2}$ refer in their studies, in a simplified way, that the superficial palmar arc has the form of a irregular curve with a distal convexity and topographically is situated in a space between the first and the second palmar pleats. The formation of this arc is a result of the anastomosis by inoculation (end to end) of the ulnar artery with the superficial palmar branch of the radial artery, which originates the arc when passes the region of the fist. This branch goes down to anastomose with the ulnar artery termination, which passes anteriorly the flexor retinaculum, constituting thus the superficial palmar arc $1,2,3,4,5,6,7,8$.

Gray $^{1}$ pointed out that this branch of the radial artery passes through, occasionally over, the muscles of thenar region. Many variations can occur regarding the anastomosis for the formation of the superficial palmar arc. The arc can be completed, in the radial side, at a variable way, by the radial artery of the index finger, the main artery of the thumb or the median artery $1,3,4,6,8,9$. Moore ${ }^{9}$ relates that the superficial palmar arc can be formed only by the ulnar artery.

According to Adachi in Keen ${ }^{10}$, there are 3 types of superficial palmar arc. One type "ulnar", which has a minimum or absent contribution of the radial artery; the second type is the "radio-ulnar" and the third is the "median-ulnar", in which the median artery is strong enough to irrigate the palm of the hand and to be part of the arc. This author also relates in his studies, that there is a very rare type of superficial palmar arc, where the median artery anastomoses with the radial artery, which has a minimum or absent contribution of the ulnar artery. This type can be called as "median-radial".

According to Huelin, Barreiro and Barcia ${ }^{11}$, the median artery can be divided in two types regarding its termination: antebrachial and palmar. The antebrachial type shows two variants, one called "atrophic" and the other "carpal". The type palmar or embryonal also gather two variants, the first called "long", which ends in the superficial palmar arc through small arterioles or supplying small vases to the subcutaneous cellular tissue; before reaches the end, the median artery sends branches which anastomose with the ulnar and radial arteries at the carpus level. The second is called "digital".

The present study aimed to observe the morphology of the superficial palmar arc and the frequency of variations in the contribution of different arterial types to its formation, in order to enable a better comprehension of the territory of the hand aiming clinical and surgical applications.

\section{Methods}

To carry out this work were used 30 hands of adult corpse, of both sexes, fixed in a watery solution of formaldehyde, of The Departamento de Anatomia da Universidade Federal de Pernambuco.

The method used was the macroscopic dissection, observing the morphology of the superficial palmar arc concerning about the variations: discontinuity of the radial portion of the superficial palmar arc; different contributions of the radial artery; and the contributions of the anterior median artery.

The dissected parts were labeled, enumerated and photographs were taken, the superficial palmar arc, was designed, to register the obtained results. The results were statistically treated in order to quantify the observed variations, and thus, determine the incidence of these variations.

The statistical analysis was made from the descriptive measurements of the proportions, represented by a graph using the test of equality of proportions, comparing with other results found in literature, with a level of trust of $95 \%$.

\section{Results}

All the analyzed pieces (100\%), showed the superficial palmar arc. From these, 18 cases $(60 \%)$ showed anastomosis among the arteries that form the arc and 12 cases $(40 \%)$ did not (Figure 1). Concerning about the type of vase that contributes for the formation of the arc (Figure. 2), from the 30 pieces studied, 11 cases $(36,67 \%)$ showed the superficial palmar arc formed by the anastomosis of the ulnar artery and the superficial palmar branch of the radial artery (classic palmar arc) (Figure 3A); 7 cases $(23,34 \%$ ) were formed only by the ulnar artery (Figure 3C); 4 cases $(13,33 \%)$, by the anastomosis of the ulnar artery and the main artery of the thumb (deep branch of radial artery) (Figure 3F); 4 cases $(13,33 \%)$, by the ulnar artery and the superficial palmar branch of the radial artery without anastomosis (Figure 3B); 3 cases (10\%), by the anastomosis of the ulnar artery with median artery of the forearm (Figure 3D); and only one case $(3,33 \%)$ formed by the ulnar artery and the median artery of the forearm without anastomosis (Figure 3E).

It was also possible, subdivide the 30 pieces, according to the classification of Adachi in Keen ${ }^{10}$, in the ulnar type $(23,34 \%)$, the radio-ulnar $(63,33 \%)$ and the median-ulnar $(13,33 \%)$. 


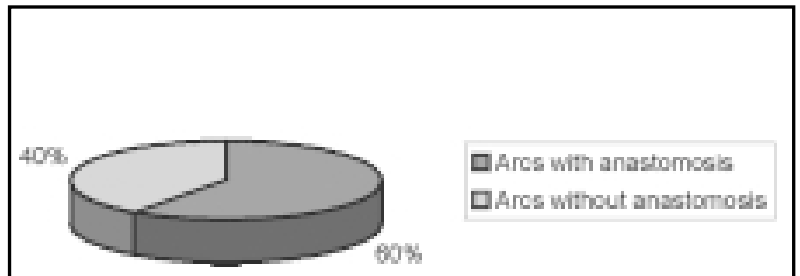

FIGURE 1 - Distribution by the occurrence of arterial anastomosis, Recife, 2001.
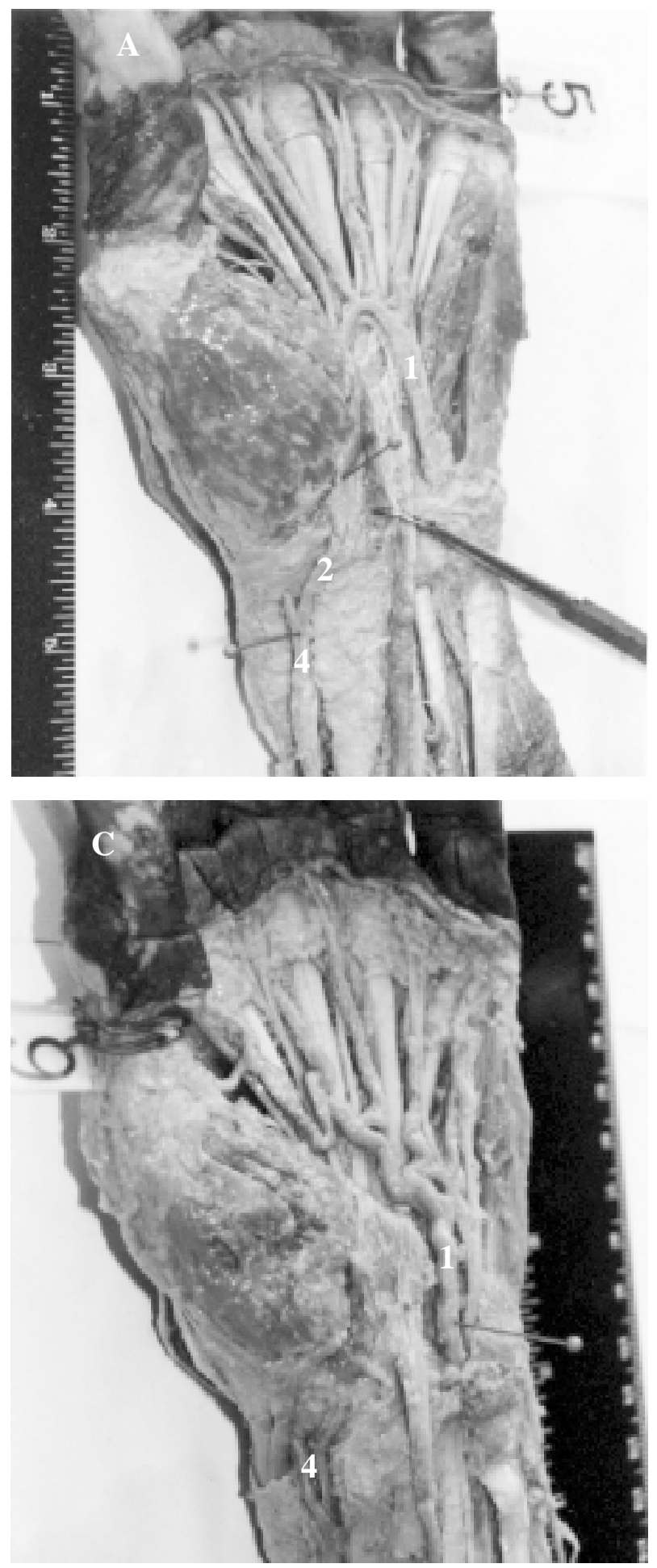

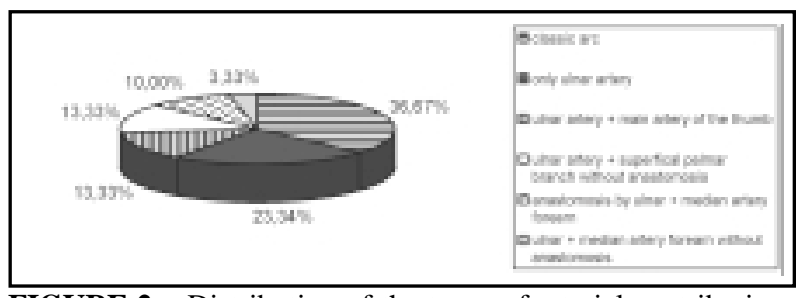

FIGURE 2 - Distribution of the types of arterial contributions for the formation of the superficial palmar arc. Recife, 2001.
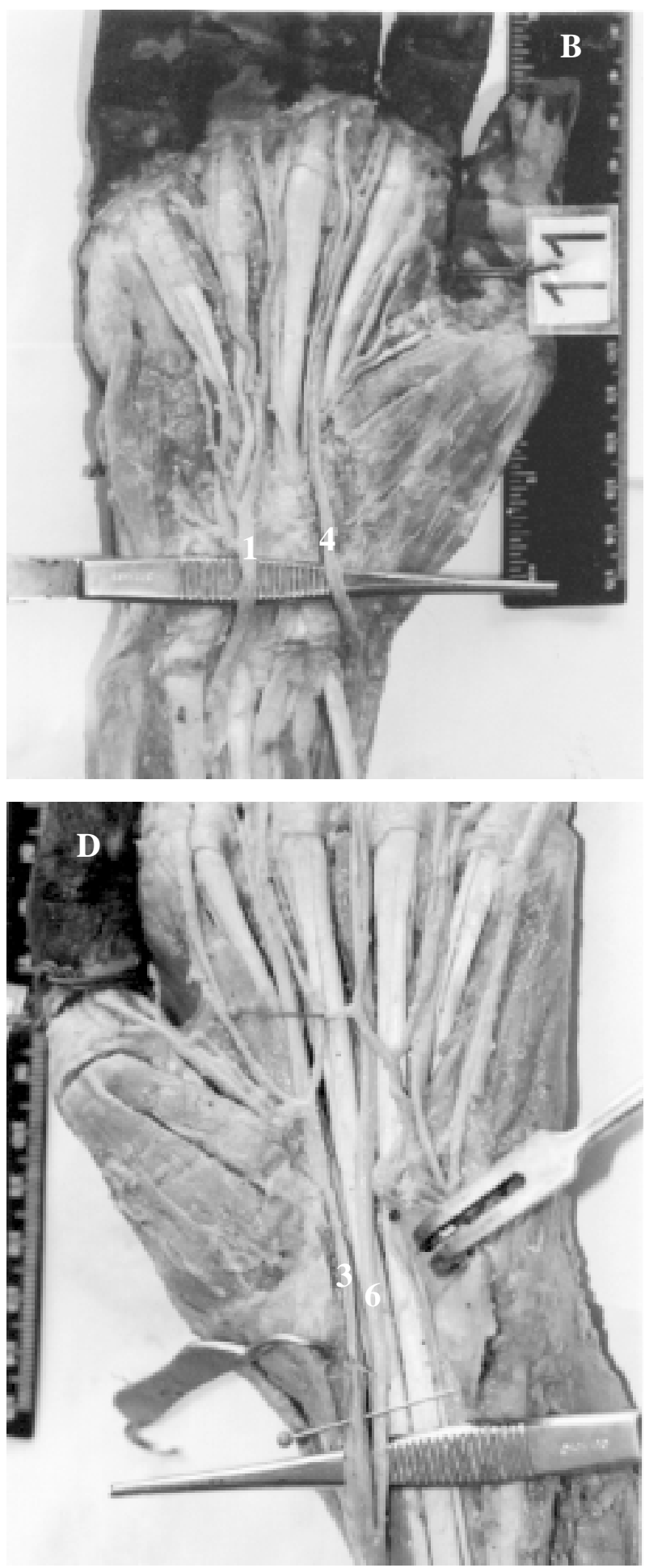

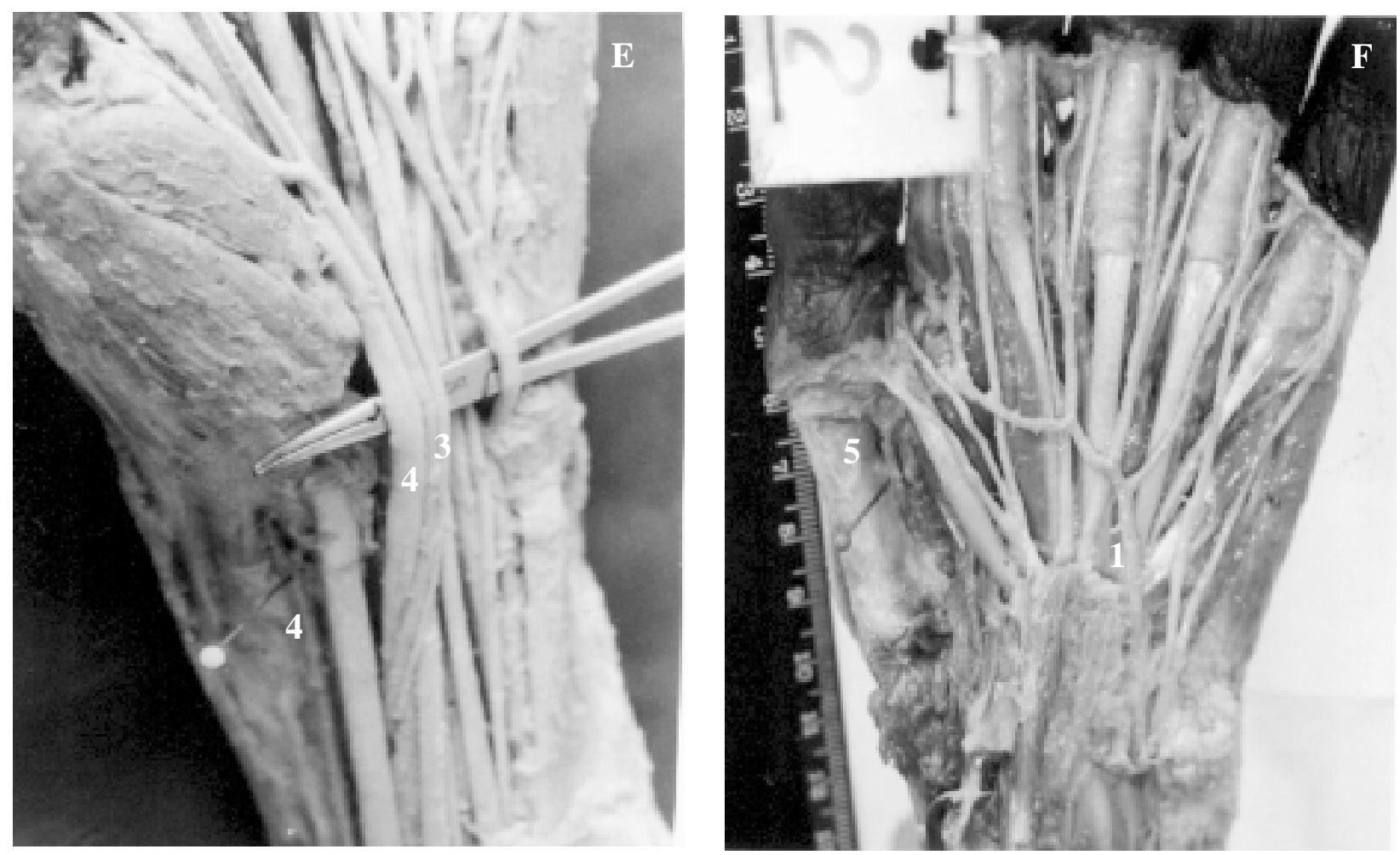

FIGURE 3 - Morphology of the superficial palmar arc. A. classic palmar arc; B. ulnar artery + superficial palmar branch of the radial artery without anastomosis; C. Arc formed only by the ulnar artery; D. ulnar artery + median artery with anastomosis; E. ulnar artery + median artery without anastomosis; F. ulnar artery + main artery of the thumb with anastomosis. 1. Ulnar artery; 2. Superficial palmar branch of the radial artery; 3. Median artery; 4. Radial artery; 5. Main artery of the thumb; 6. Median nerve; 7. Ulnar nerve.

\section{Discussion}

Concerning about the frequency of the superficial palmar arc, 80 hands of corpse were studied by Ozkus et $a l^{12}$, they verified that 78 of the specimens $(97,5 \%)$ showed the superficial palmar arc and only 2,5\% matching 2 samples did not. While at the present study all analyzed samples showed the arc.

Although the arc is classicaly described with the presence of the anastomosis, the superficial palmar arc can be found without anastomosis. Olave et al $l^{13}$ examined 60 hands of 30 corpse, from these, 66,7\% of the superficial palmar arc showed anastomosis and $33,3 \%$ did not. These results (Table 1) are according to our results which found anastomosis em 18 cases $(60 \%)$, the differences found were insignificant, from statistical view, using the Qui-quadrado test of equality of distribution with a level of trust of $95 \%$.

TABLE 1 - Distribution by the occurrence of arterial anastomosis.

\begin{tabular}{l|c|c}
\hline Types of arcs & Olave et al & Araújo et al \\
\hline Arcs with anastomosis & $66,7 \%$ & $60 \%$ \\
\hline Arcs without anastomosis & $33,3 \%$ & $40 \%$ \\
\hline
\end{tabular}

Olave et $a l^{13}$ showed in their studies the predominance of the classic palmar arc and the arc formed by the anastomosis of the ulnar artery and a deep branch of the radial artery, each one matching $30 \%$, in our studies prevailed the classic palmar arc $(36,67 \%)$. Concerning about the arc formed by the ulnar artery and the deep branch of the radial artery, we observed that Olave et al do not specify which branch of the radial artery contributed for the formation of the arc. Though the literature describes two types of deep branches that can complete the arc, the radial type of the index finger and the main type of the thumb. Our studies verified the main type of the thumb joined to the ulnar artery $(13,33 \%)$. Olave $e t a l^{13}$ relates the 
existence of the arcs formed by the ulnar and the median artery of the forearm without anastomosis $(6,7 \%)$, which in our studies prevailed with 3,33\%. The same contribution was verified at the present study, but with anastomosis, matching $10 \%$ of the cases, while Olave et $a l^{13}$ related $3,3 \%$. In this study, 23,34\% of the arcs were formed only by the ulnar artery, while $5 \%$ were found in the studies of Olave et $a l^{13}$. These authors identified in theirs studies the presence of the arc formed by the anastomosis of the ulnar artery and the superficial palmar branch of the radial artery, joined to the median artery $(3,3 \%)$, and the arc formed by the ulnar artery and the deep branch of the radial artery without anastomosis $(6,7 \%)$, these results show, by the Quiquadrado test of equality of distribution with a level of trust of $95 \%$, that these differences found are statistically significant (Table 2).

TABLE 2 - Distribution of the types of arterial contributions for the formation of the superficial palmar arc.

\begin{tabular}{l|c|c}
\hline Types of arcs & Olave et al & Araújo et al \\
\hline Ulnar + deep branch of the radial artery with anastomosis & $30 \%$ & $13,33 \%$ \\
\hline Ulnar + superficial palmar branch without anastomosis & $15 \%$ & $13,33 \%$ \\
\hline Ulnar + deep branch of the radial artery without anastomosis & $6,7 \%$ & $0 \%$ \\
\hline Ulnar + median artery without anastomosis & $6,7 \%$ & $3,33 \%$ \\
\hline Ulnar & $5 \%$ & $23,34 \%$ \\
\hline Ulnar + median artery with anastomosis & $3,3 \%$ & $10 \%$ \\
\hline Ulnar + superficial palmar branch of the radial artery with anastomosis, & $3,3 \%$ & $0 \%$ \\
\hline joined the median artery & $30 \%$ & $36,67 \%$ \\
\hline Classic palmar arc &
\end{tabular}

Adachi in $\mathrm{Keen}^{10}$, described the ulnar type as the more popular (59\%), followed by the radio-ulnar (32\%) and the median-ulnar $(9 \%)$. In our case there is a bigger prevalence of the radio-ulnar type $(63,3 \%)$, followed by the ulnar $(23,34 \%)$ and the median-ulnar $(13,33 \%)$. The differences of our studies are statistical. Confirmed by the application of Qui-quadrado test of equality of distribution. With a level of trust of $95 \%$, we obtained 54,31 as a value of statistic which is bigger than the value listed $(5,99)$, and therefore we concluded that there is a significant difference between our studies and the studies of Adachi in Keen ${ }^{10}$ (Table 3).

TABLE 3 - Distribution of the types of arterial contributions for the formation of the superficial palmar arc.

\begin{tabular}{l|c|c}
\hline Types of arcs & Adachi in Keen & Araújo et al \\
\hline Ulnar & $59 \%$ & $23,34 \%$ \\
\hline Radio-ulnar & $32 \%$ & $63,33 \%$ \\
\hline Median-ulnar & $9 \%$ & $13,33 \%$ \\
\hline
\end{tabular}

\section{Conclusion}

Thus, the results obtained at the present study showed the prevalence of the classic pattern, although the variations of morphology and the types of arterial contribution for the formation of the superficial palmar arc, are also frequent, showing the importance of these variations to improve the knowledge of the territory of the hand aiming clinical and surgical applications.

\section{References}

1. Gray H. Anatomia. 2ed. Rio de Janeiro: Guanabara Koogan; 1977.

2. Testut L, Latarjet A. Tratado de anatomia humana. Barcelona: Salvat editores; 1977.

3. Gardner E, Gray DJ, O' Rahilly R. Anatomia. 4ed. Rio de Janeiro: Guanabara Koogan; 1988.

4. Dângelo JG, Fattini CA. Anatomia humana sistêmica e segmentar. 2ed. Rio de Janeiro: Atheneu; 1998. 
5. Lockhart RD, Hamilton GF, Fyfe FW. Anatomia do corpo humano. 2ed. Rio de Janeiro: Guanabara Koogan; 1983.

6. Latarjet M, Liard AR. Anatomia humana. 2ed. São Paulo: Panamericana; 1993.

7. Castro S. Anatomia fundamental. 2ed. São Paulo: McGrawHill; 1976.

8. Snell RS. Anatomia. 5ed. Rio de Janeiro: Guanabara Koogan; 1999.

9. Moore KL. Anatomia orientada para a clínica. 3ed. Rio de Janeiro: Guanabara Koogan; 1994.

10. Keen JA. Study of the arterial variations in the limbs, with special reference to simetry of vascular patterns. Am J Anat 1961; 108: 245-61.

11. Huelin JGV, Barreiro FJ, Barcia EC. Etude radio-anatomique de l'artère médiane. Acta Anat 1979; 105: 250-5.
12. Ozkus K, Pestelmaci T, Soyluoglu AI, Akkin SM, Ozkus HI. Variations of the superficial palmar arch. Folia Morphol (Warsz) 1998; 57 (3): 251-5.

13. Olave E, Prates JC, Mandiola E, Del Sol Calderón M, Gabrielli C. Formaciones arteriales superficiales de la palma de la mano. Rev Chil Anat 1993;11 (1): 35-40.

\section{Acknowledgment}

We are greatful to Teacher Maria Cristina Falcão Raposo, from Departamento de Estatística of Universidade Federal de Pernambuco, and Sr. Wilson Cavalcanti.

Moraes SRA, Araújo TN, Silva AR, Paula AR, Salgado JL. Variações morfológicas do arco palmar superficial. Acta Cir Bras [serial online] 2003 Maio-Jun;18(3). Disponível em URL: http://www.scielo.br/acb.

RESUMO - Objetivo: Verificar a morfologia do arco palmar superficial e a frequiência das variações quanto à contribuição de outras artérias para a sua formação. Métodos: Foram utilizadas 30 peças cadavéricas fixadas em solução aquosa de formol e estudadas pelo método de dissecação macroscópica. As peças analisadas foram desenhadas e fotografadas e os resultados obtidos, tratados estatisticamente, aplicando o teste de igualdade de proporções, com o nível de confiança de $95 \%$. Resultados: Em 100\% da amostra, observou-se o arco palmar superficial. Destas, 18 casos (60\%) apresentavam anastomose entre as artérias formadoras do arco e 12 casos (40\%) não. Quanto à contribuição arterial para a formação do arco, foram obtidos os seguintes resultados: 11 casos $(36,67 \%)$ eram formados pela anastomose da artéria ulnar com ramo superficial da artéria radial; 7 casos $(23,34 \%)$ formados pela artéria ulnar apenas; 4 casos $(13,33 \%)$ pela artéria ulnar e ramo palmar superficial da artéria radial sem anastomose; 4 casos $(13,33 \%)$ pela anastomose da artéria ulnar com artéria principal do polegar; 3 casos (10\%) formados pela anastomose da artéria ulnar com artéria mediana do antebraço; 1 caso $(3,33 \%)$ formado pela artéria ulnar e artéria mediana sem anastomose. Conclusão: Estes resultados mostram a incidência do padrão clássico e variações na morfologia e nos tipos de contribuições para a formação do arco palmar superficial.

DESCRITORES - Arco palmar superficial. Anastomose. Morfologia.

Conflict of interest: none

Financial source: none

Correspondence:

$\mathrm{Dr}^{\mathrm{a}}$ Sílvia Regina Arruda de Moraes

Rua Capitão Rui Lucena, 160/501

50.070-080 Recife - PE

Tel: (81)3421-1731 / 9904-8714

silvia@ufpe.br

Data do recebimento: $26 / 01 / 2003$

Data da revisão: 09/02/2003

Data da aprovação: 18/02/2003 